\title{
Guns or Food: On Prioritizing National Security over Global Poverty Relief ${ }^{1}$
}

\begin{abstract}
Political realists claim that international relations are in a state of anarchy, and therefore every state is allowed to disregard its moral duties towards other states and their inhabitants. Realists argue that complying with moral duties is simply too risky for a state's national security. Political moralists convincingly show that realists exaggerate both the extent of international anarchy and the risks it poses to states who act morally. Yet moralists do not go far enough, since they do not question realism's normative core: the claim that when national security is really at risk, states are allowed to disregard their moral duties. I contend that there is at least one moral duty that states should not disregard even if their inhabitants are at risk of death by military aggression: the duty to reduce extreme global poverty. The reason is that even granting that national security is about securing individuals' right to life, global poverty relief is about that as well.
\end{abstract}

Keywords: anarchy; global poverty; national security; political realism; right to life.

\section{Introduction}

Australia, the U.K., and the U.S. are currently considering reducing their foreign aid budget and increasing their national security budget. ${ }^{2}$ Political realists would probably find this trend acceptable, since they regard national security as having priority over a state's moral pursuits, especially over moral pursuits benefiting people in other states. Realists argue that in an international arena devoid of authority, acting morally towards others is simply too dangerous.

Critics have pointed out the many flaws in the realist view. Acting morally in the international arena does not always come at a cost for national security (in fact, acting morally may sometimes enhance security). International relations are not devoid of any authority. States are subject to authoritative international rules and governance institutions which facilitate cooperation and relieve states

Winner of the 2017 Annual Jonathan Trejo-Mathys Essay Prize.

2 Washington Post Staff, 'What Trump proposed cutting in his 2019 budget', The Washington Post, February 16, 2018, <https://www.washingtontimes.com/news/2018/feb/12/trump-releases-new-federal-budget-with-big-hike-fo/> (Accessed: 28 February 2018); Emma Vardy, 'Foreign aid to be shifted to support UK policy, Johnson says', BBC News, December 31, 2018, <http://www.bbc.com/news/uk-42528712> (Accessed: 28 February 2018); Merran Hitchick, 'Defence Spending up in Budget, Foreign Aid down', The Guardian, May 9, 2017, <https://www.theguardian.com/ australia-news/2017/may/o9/defence-spending-up-in-budget-foreign-aid-down> (Accessed: 28 February 2018). 
of having to be primarily concerned with security. ${ }^{3}$

However, critics of realism do not go far enough. They leave realism's normative core untouched. Implicitly - and sometimes even openly - critics grant that in those situations in which national security is truly at stake states are allowed to leave moral concern for foreigners aside if necessary. This is a significant concession, since (as I argue below) there are indeed situations in which states are forced to tradeoff between national security and moral concern for foreigners. My aim in this article is to develop the critique against realism further by showing that realism's normative core can be challenged. National security does not have priority over at least one moral duty towards foreigners: the duty to reduce extreme global poverty.

This article is structured as follows. The first section describes in some detail the strongest argument that realists offer for their view, what I call the 'argument from anarchy.' The second section shows the main shortcomings in current critiques against that argument. The third section assesses and rejects the main normative premise in the anarchy argument. The fourth section considers two possible realist replies which are based on the idea of role duties and the idea of reasonable priority for compatriots.

\section{The realist argument from anarchy}

The kind of international political realism I am concerned with in this article is defined by the claim that national security has priority over, or outweighs, moral concerns. National security or defense is the activity of protecting a state, its inhabitants, its community, or some national value from violent aggression; or, alternatively, national security is the state of affairs in which protection from aggression adequately obtains. Realists offer different arguments for claiming that national security has priority. Here I focus on what is often regarded as the strongest realist argument, ${ }^{4}$ what I call the 'argument from anarchy.' It can be summarized as follows:

A. The international arena is anarchic.

B. Complying with moral duties in anarchic arenas always comes at a cost for national security.

C. National security has priority over all moral duties.

D. Therefore, every state is always allowed to disregard its moral duties towards other states and their inhabitants.

3 Charles R. Beitz, Political Theory and International Relations (Princeton, N.J.: Princeton University Press, 1979), Ch. 1; Simon Caney, Justice beyond Borders (Oxford: Oxford University Press, 2005), p. 136-140; Jack Donnelly, 'Twentieth-Century Realism', in Traditions of International Ethics, ed. Terry Nardin and David R. Mapel (Cambridge, UK: Cambridge University Press, 1993), 85-111.

4 Beitz (1979), p. 27. 
The argument from anarchy does not necessarily assume moral skepticism as a starting point. On the contrary, the argument is compatible with claiming that every state has moral duties, even towards other states and their inhabitants. But the argument highlights that, given certain structural features of international relations, acting morally towards others compromises national security. Now, national security should be the paramount concern for a state. Therefore, states are allowed to disregard less important concerns, including all moral concerns for other states and their inhabitants. Let us see the premises in this argument in more detail.

Premise A in the argument from anarchy claims that international relations are anarchic. In the international relations literature there are several definitions of 'anarchy,' all of which refer to the absence of (de facto) authority. ${ }^{5}$ Some definitions refer to the absence of authority in general, while others refer to the absence of some specific kind of authority (such as a government, an authorized enforcement agent, etc.). ${ }^{6}$ For the argument from anarchy to work, there is no need to refer to a specific kind of authority. Anarchy can be defined by the absence of an authority of any kind that is effective in restricting aggressive behavior between agents.

When relations between agents are anarchic, agents are unsure whether others will behave aggressively towards them. Adapting to this sort of uncertainty may require considerable time and energy. According to realist authors, international relations are indeed anarchic. ${ }^{7}$ These authors claim that there is no authority effectively restricting aggressions by states. ${ }^{8}$ Thus, states have to devote considerable efforts to making sure that no state will be aggressive towards them, and to defending themselves when others do act aggressively.

Premise B says that complying with moral duties in anarchic arenas always comes at a cost for national security, so 'states in anarchy cannot afford to be moral. ${ }^{9}$ Incompatibility, or conflict, between two aims occurs when those aims cannot be simultaneously realized because realizing each of them requires spending resources from a single limited pool of resources (or capital, goods,

5 A rule (or set of rules) has de facto authority when an agent (or a set of agents) habitually regards the rule as binding and obeys it. Thomas Christiano, 'Authority', The Stanford Encyclopedia of Philosophy, 2013, sec. 1, <http://plato. stanford.edu/archives/spr2013/entries/authority/> (Accessed: 30 August 2017).

6 Jack Donnelly, 'The Discourse of Anarchy in IR', International Theory 7/3 (2015), 393-425, p. 410.

7 Robert J. Art and Kenneth N. Waltz, The Use of Force (Lanham: Rowman \& Littlefield, 1983), p. 6; John Hermann Herz, The Nation-State and the Crisis of World Politics. Essays on International Politics in the Twentieth Century (New York: McKay, 1976), p. 10.

8 A serious shortcoming in realist theorizing of international relations is its focus on states. There are other kinds of agents in global politics that influence security and poverty (such as the U.N.). Beitz (1979), p. 41; Thomas Pogge, Politics as Usual: What Lies behind the pro-Poor Rhetoric (Cambridge, UK; Malden, MA: Polity, 2010), pp. 34-36. Some of these other agents probably also face decisions involving trade-offs between security and poverty.

9 Art and Waltz (1983), p. 6. 


\section{GUNS OR FOOD: ON PRIORITIZING NATIONAL SECURITY OVER GLOBAL POVERTY RELIEF}

etc.). Acting morally has costs in terms of economic resources, time, diplomatic capital, or other. Realists claim that when resources from a state's limited pool are spent on moral pursuits, this always means that less resources are available for meeting international security costs. There is also a moderate version of premise B which claims that spending resources on moral pursuits often - not always - comes at a cost for national security. And there is a weak version as well, which claims that spending resources on moral pursuits at least sometimes comes at a cost for national security. All three versions highlight that states do face trade-offs between national security and moral concerns, so a priority ordering between those two considerations is required.

It may seem that there is anarchy within states as well. After all, states are not completely effective in restricting aggression between their own inhabitants. For that reason, most people protect themselves by locking their doors, moving to neighborhoods with reduced crime rates, etc. ${ }^{10}$ Moreover, these defensive expenditures demand resources which individuals cannot use for other ends. So perhaps it is not only states, but also individuals who cannot afford to be moral.

Realists answer by adding a second condition to their definition of anarchy. Anarchy is not only the absence of an authority which effectively restricts aggression, but an authority which effectively restricts aggression to the point of preventing the 'security dilemma.'11 The security dilemma has the following form. A state $\mathrm{S}$ can never be sure whether another state $\mathrm{T}$ will remain pacific or will become aggressive. If $\mathrm{S}$ consequently chooses to increase its national security by spending more resources on defensive means, state T's national security decreases, because S's defensive means can almost always be used for aggression as well. For example, state S's newly recruited defensive soldiers can easily be employed for invading $\mathrm{T}$ as well. Even if $\mathrm{S}$ is currently non-aggressive, $\mathrm{T}$ can never be sufficiently sure that $\mathrm{S}$ will remain so, since internal political changes in $\mathrm{S}$ may lead $\mathrm{S}$ to adopt an aggressive stance in the future. Now, $\mathrm{T}$ could respond to its diminished security by arming itself more, but that will in turn decrease S's security, leading to a race with spiraling security costs. Within a state territory, on the other hand, individuals enjoy a higher degree of reassurance, and are able to deal with any remaining insecurity by using means that do not decrease other individuals' security. My buying a door lock or moving to a safer neighborhood does not trigger a security race with other individuals. Protection from aggression is therefore substantially costlier for states, who thus face much more acute trade-offs between security and moral considerations. States cannot afford to be moral, individuals can.

10 Jervis, Robert. 'Cooperation Under the Security Dilemma', World Politics 30/2 (1978), 167-214, p. 170.

11 Jervis (1978), p. 169. 
Premise C claims that when states pursue national security they are allowed and even required to disregard moral commitments if necessary. ${ }^{12}$ Let me clarify the scope and grounds of this claim.

In terms of scope, the realist premise $\mathrm{C}$ seems to extend to all moral duties, including the duties to reduce global poverty. The claim that states have a duty to reduce extreme global poverty is widely accepted in contemporary discussions on global justice, both by statist and cosmopolitan authors. ${ }^{13}$ In this article I take it for granted that states have a duty to reduce extreme global poverty, and my critique should be taken as addressing only those realists who do not deny that there is such a duty. These realists merely claim that the duty is outweighed by national security. Now, it is true that realist authors rarely speak about moral duties to reduce global poverty, or about how these duties measure up against issues of national defense. ${ }^{14}$ However, the realist claim that national security has priority over moral considerations is usually stated in a general form, so in principle it covers all moral duties. In any case, regardless of whether realist authors implicitly or explicitly claim that the alleged priority of national security also extends to global poverty reduction, the claim is worth discussing because it is often held in public discourse. ${ }^{15}$

Regarding the grounds of premise $\mathrm{C}$ there are two main views: collectivism and individualism. According to collectivism, national security has priority over all other considerations because foreign violent aggression may threaten

12 Raymond Aron, Peace and War; a Theory of International Relations (Garden City, N.Y.: Doubleday, 1966), p. 580; Art and Waltz (1983), p. 6; Niccolo Machiavelli, The Prince and the Discourses, ed. Max Lerner (New York: Random House, 1950), p. 65; Hans J. Morgenthau, Politics among Nations: The Struggle for Power and Peace, ed. Kenneth W. Thompson and W. David Clinton (Boston: McGraw-Hill, 2006), p. 10.

13 Statist who claim that states have duties to reduce global poverty include Michael Blake, 'Distributive Justice, State Coercion, and Autonomy', Philosophy \& Public Affairs 30/3 (2001), 257-296, p. 271; David Miller, National Responsibility and Global Justice (Oxford: Oxford University Press, 2007), p. 164;166.; Thomas Nagel, “The Problem of Global Justice', Philosophy \& Public Affairs 33/2 (2005), 113-147, p. 118. Cosmopolitans who claim that states have duties to reduce global poverty include Thomas Pogge, World Poverty and Human Rights : Cosmopolitan Responsibilities and Reforms (Cambridge; Malden, MA: Polity, 2002); Darrel Moellendorf, Cosmopolitan Justice (Boulder, CO: Westview Press, 2002); Kok-Chor Tan, Justice without Borders: Cosmopolitanism, Nationalism, and Patriotism (New York: Cambridge University Press, 2004).

14 Some realist authors do mention the duty to reduce global poverty. Hans Morgenthau, for example, discusses development aid and he seems to imply that aid should not be given to states that could become enemies. (Hans J. Morgenthau, 'A Political Theory of Foreign Aid', The American Political Science Review 56/2 [1962], p. 307). It seems that in Morgenthau's view, then, national security has priority over poverty reduction. On the other hand, some contemporary realist authors address global poverty, but they do not address the issue of potential conflicts with national security (Terry Nardin, 'Realism and Right: Sketch for a Theory of Global Justice.' In Ethical Reasoning in International Affairs, ed. Cornelia Navari (London: Palgrave Macmillan, 2013), 43-63; Matt Sleat, 'The Value of Global Justice: Realism and Moralism', Journal of International Political Theory, 12/2 [2016], 169-184), or when they do address those conflicts they do not focus on which consideration has normative priority, but on which policy strategy could dissolve the conflict (Duncan Bell, 'Political Realism and International Relations', Philosophy Compass 12/2 (2017), 1-12).

15 See for example David Davenport, 'Donald Trump's Budget Raises A Question Of The Ages: What Should Government Do (And Not Do)?', Forbes (March 8, 2017), <https://www.forbes.com/sites/daviddavenport /2017/03/o8/donald-trumps-budget-raises-a-question-of-the-ages-what-should-government-do-and-not-do/> (Accessed: 30 August 2017). 
important collective values, such as political self-determination, the continued existence of the state, territorial integrity, and cultural identity. Some realists regard these values as supreme. ${ }^{16}$ According to individualism, on the other hand, national security has priority over all other considerations because foreign aggression threatens the lives of individual inhabitants. Military invasions (and other forms of foreign violent aggression, including international terrorism) against one's country should be prevented at all costs because they are often fatal to many human beings, including non-combatants.

In what follows I will deal with premise $\mathrm{C}$ in its individualist version only. The main reason (which I simply take for granted here) is that individual survival matters more than any collective value. Thus, if I manage to show that the individualist view is unable to support premise $\mathrm{C}$, then this premise is probably indefensible in its collectivist interpretation as well. Moreover, even if we granted that individual survival does not matter more than collective values, I believe that complex questions become more tractable when each part is treated separately. In that sense, this article could be taken as dealing with only part of the question whether national security has priority over moral duties, i.e., the part that deals with whether securing a state inhabitants' survival (which would be just one reason among others why national security is important) really has priority over moral duties.

\section{An incomplete moralist critique}

Realism is opposed to what I will call 'moralism', the view that moral considerations cannot justifiably be put aside even for urgent political reasons. Current moralist objections to the argument from anarchy mostly focus on rejecting premises $\mathrm{A}$ and $\mathrm{B}$.

Regarding premise A, many critics of realism have noted that it is simply not true that international relations are always and everywhere anarchic. International law includes rules of war (not only in bello, but also ad bellum) which in some cases effectively restrict the use of aggressive force. ${ }^{17}$ There are several coercive mechanisms in place for enforcing compliance with rules of war, ranging from mild sanctions such as international disapproval and censure, to stronger sanctions such as embargoes and threats of exclusion from beneficial agreements and organizations. ${ }^{18}$ States are also capable of avoiding the security dilemma by increasing their defense through means that do not significantly decrease other states' security. Such means include fortifications,

16 Leo Strauss, Natural Right and History (Chicago: University of Chicago Press, 1953), p. 160.

17 Oona A. Hathaway, 'Between Power and Principle: An Integrated Theory of International Law', The University of Chicago Law Review. University of Chicago. Law School 72/2 (2005), 469-536.

18 Beitz (1979), p. 47. 
fixed weapons, and mine fields. ${ }^{19}$

Critics of realism also highlight other structural elements in international relations that reduce the likelihood of aggression and increase reassurance. First, states are often interdependent in economic, military, climatological, and other areas. The level of employment, economic growth, health, etc. in one state depend heavily on the degree of cooperation with other states. Since states are interested in economic growth, employment, etc., and military aggression disrupts international cooperation, interdependence makes aggression less likely. ${ }^{20}$ Another structural element that critics point out is that world powers such as the U.S. enjoy a degree of military and economic control over other states that seems to protect them from many of the threats posed by international $\operatorname{anarchy.}^{21}$

Another problem with premise A is that most foreign military aggressions do not primarily aim at killing individuals. Needless to say, genocidal and massmurder aggression is not at all absent in human history, but currently many wars take the form of 'political aggressions,' i.e. aggressions that primarily aim at obtaining political or material advantage. ${ }^{22}$ Political aggression usually poses mere conditional threats to life: aggressors only kill if they are met with resistance. This is important because premise A is supposed to work in conjunction with premise $\mathrm{C}$, which in turn is interpreted in terms of the individual right to life. According to this interpretation, the realist argument claims that anarchy justifies immoral behavior because if a state acts morally in anarchy it risks its inhabitants' survival. But if the risks in anarchy are often mere political and material loss, not loss of life, then conclusion D is considerably weakened.

These critiques have some limits. Although they show that premise A is false as a claim about all relations between agents in the international arena, it may still be true that relations between some agents are sometimes anarchic and risky. Indeed, during some periods of time there are no effective restrictions on aggression: sometimes some states do not regard international rules as binding in their case, or they are not deterred by sanctions. Moreover, the risk of being a victim of aggression - and mass-murder aggression in particular - is real even for affluent states, especially in a nuclear age. ${ }^{23}$ Therefore, a moderate version of premise A is still plausible: some international relations are during some

19 Jervis (1978), p. 203.

20 Beitz (1979), p. 42-45.

21 Ibid. p. 41.

22 David Rodin, 'The Myth of National Self-Defence', in The Morality of Defensive War, ed. Cécile Fabre and Seth Lazar (Oxford: Oxford University Press, 2014), pp. 81-82.

23 David P. Gauthier, The Logic of Leviathan: The Moral and Political Theory of Thomas Hobbes (Oxford: Clarendon Press, 1979), pp. 207-208. 
periods of time anarchic and risky in terms of national security. So it is worth asking if to that limited extent and in those cases national security has priority over moral duties.

Premise B is also problematic. This premise, recall, says that national security and moral aims are incompatible. I believe that moralists convincingly reject this premise in its strong version. National security is not completely incompatible with acting morally in the international arena. Acting morally towards foreigners often has no costs (and it sometimes brings benefits, see below) for national security: 'issues of foreign policy do not all hang together, with every other issue being connected to survival.'24

However, premise B in its moderate and weak versions is convincing. Consider for example this article's main concern, the moral duty to reduce extreme global poverty. Certainly, reducing global poverty sometimes requires spending resources. So it seems that sometimes a choice needs to be made whether those resources should not be used for national security purposes instead. ${ }^{25}$ Consider three concrete examples.

The most straightforward example are national budget decisions. Every government has to choose how to distribute its limited resources between the national security budget and the foreign aid budget. Affluent states currently spend considerable amounts of money and human resources on their militaries and their defensive systems - including power-projection and deterrence assets - and they also spend some money and human resources on foreign aid. ${ }^{26}$ Since the resource pool is always limited, cutting the national security budget would enable them to increase their foreign aid budget, and vice versa. So a decision needs to be made as to where to allocate available resources. Besides the cases of Australia, the U.K., and the U.S. that were mentioned in the introduction, consider now the current situation in South Korea. During the last 30 years this state has been steadily increasing its spending on official development aid, now reaching $0.14 \%$ of its gross national income. ${ }^{27}$ However, increasing tensions with neighboring North Korea may demand additional military spending (for example, spending on more missile shields). Cutting back on development aid could help gather the required funds. South Korea should therefore decide

24 Allen E. Buchanan, Human Rights, Legitimacy, and the Use of Force (Oxford: Oxford University Press, 2010), p. 118.

25 In this article I assume that within the territory of affluent states there is no extreme poverty. This is merely a simplifying assumption. National security could of course clash with domestic poverty relief as well. This article's conclusions mostly apply to such cases as well.

26 World Bank, Official Development Assistance (ODA). <https://data.oecd.org/oda/net-oda.htm> (Accessed: 30 August 2017). World Bank, Military Expenditure (\% of GDP). <http://data.worldbank.org/indicator/MS.MIL.XPND. GD.ZS> (Accessed: 30 August 2017).

27 Organisation for Economic Co-operation and Development (OECD), 'Net ODA', <https://data.oecd.org/oda/net-oda. htm> (Accessed: 30 August 2017). 
whether trading off foreign aid for national security is permissible in this case, or whether the needed defense funds should come from another source.

Of course, budget allocation choices are usually not between just two concerns - security and poverty - , but between an appallingly larger number of important concerns including education, infrastructure, health, science, arts, etc. So it may seem that a focus on security and poverty is arbitrary, since there is no reason why additional funds for foreign aid should come from cuts to the security budget as opposed to, say, cuts to the arts budget. Now, the very claim that additional funds for foreign aid should not come from the security budget shows an implicit commitment to the claim that security has priority over foreign aid, or at least that both are equally important. This implicit commitment stands in need of justification.

The second example are some cases of economic sanctions against countries for geopolitical reasons. U.N. sanctions against Iraq from 1990 to 2003 and against North Korea since 2013 were publicly justified in terms of national security. These countries allegedly possessed (or were developing) weapons of mass destruction that could be used against other countries. Now, economic sanctions are often linked with increased poverty rates. ${ }^{28}$ Thus, whenever there are no other equally effective means (besides sanctions) to achieve an important national security aim, then this aim is in conflict with world poverty reduction.

The third example are cases where global poverty reduction is pursued through international institutional reform. Reforming international laws on trade barriers, national debt, intellectual property, weapons and resource trade, and other areas could have a substantial positive impact on the worldwide incidence of poverty. ${ }^{29}$ Achieving these reforms through the relevant international governance institutions would require considerable negotiation efforts. Agents trying to get the reforms through would need to spend political capital, including both domestic political capital and diplomatic capital. But these types of political capital are also required to maintain national security. Since political capital is scarce, agents face a choice between spending it on national security or on global poverty reduction.

A common reply to premise B and to the sort of examples that I have just provided is that fighting poverty abroad may actually strengthen national

28 Matthias Neuenkirch and Florian Neumeier, 'Always Affecting the Wrong People? The Impact of US Sanctions on Poverty', University of Trier Research Papers in Economics, 3/15 (2015). <https://papers.ssrn.com/sol3/papers. cfm?abstract_id=2590259> (Accessed: 30 August 2017).

29 Thomas Pogge and Mitu Sengupta, 'Rethinking the Post-2015 Development Agenda: Eight Ways to End Poverty Now', Global Justice: Theory Practice Rhetoric 7 (2014), 3-11; Fernando R. Tesón and Jonathan Klick, 'Global Justice and Trade', in Global Justice and International Economic Law: Opportunities and Prospects, ed. Chios Carmody, Frank J. Garcia, John Linarelli (New York: Cambridge University Press, 2012), 217-60. 


\section{GUNS OR FOOD: ON PRIORITIZING NATIONAL SECURITY OVER GLOBAL POVERTY RELIEF}

security. Consider for instance international terrorism, which is currently a major national security concern in affluent countries (and non-affluent countries as well). It could be argued that poverty is conducive to increased international terrorist activity, so fighting poverty could help curb terrorism. ${ }^{30}$ Conversely, it could be argued that spending in military assets is helpful in reducing world poverty. For example, humanitarian military interventions - such as the British intervention in Sierra Leone in 2000, which is widely regarded as successful can stop civil wars, which often cause poverty. Cuts on military spending could decrease affluent states' capacity for similar benign interventions.

Notice that pointing to these important complementarities between the two aims (national security and poverty reduction) are not enough to reject premise B. The critics need to show that fighting poverty is the best available means to increase national security (or, conversely, that military spending is the best means to reduce global poverty). Otherwise, there could still be a conflict between reducing poverty as much as possible and increasing national security as much as possible. My view is that although it is true that in some cases the best available means to increase national security are at the same time the best available means to reduce global poverty, in many cases the best means for one end will be a suboptimal means for the other end. So premise B in its weak version still holds.

The most serious shortcoming in most moralist critiques against realism, however, is that they leave premise $\mathrm{C}$ unchallenged. Those critiques focus on premises $\mathrm{A}$ and $\mathrm{B}$, but they seem to grant that if premise $\mathrm{A}$ and $\mathrm{B}$ were right, then the realist conclusion would follow.

Consider for example how Charles Beitz rejects what he calls the 'Hobbesian argument for international skepticism.' ${ }^{31}$ Beitz reviews several versions of this argument. One of those versions is fundamentally the same as the argument from anarchy. ${ }^{32}$ As mentioned above, Beitz convincingly rejects premises A and $B$ in the argument from anarchy by showing that even in the absence of a statelike supranational authority there is currently a reliable expectation that most states will comply with rules against military aggression. ${ }^{33}$ However, Beitz seems to concede that premise $\mathrm{C}$ (in its individualist version) is fundamentally correct. He claims that when an action is required in order to preserve the lives of a state's inhabitants, the action is 'relatively unobjectionable' (i.e., unobjectionable from

30 Susan E. Rice, 'The National Security Implications of Global Poverty' in Confronting Poverty: Weak States and U.S. National Security, edited by Susan E. Rice, Corinne Graff, and Carlos Pascual, (Washington, D.C.: Brookings Institution Press, 2010), 1-22, pp. 28-9.

31 Beitz (1979), p. 14.

32 Ibid.pp. 27-52.

33 Ibid.pp. 46-48. 
the moral point of view), and it is 'prima facie acceptable.'34

Similarly, other critics of international political realism plausibly show that premise $\mathrm{B}$ in the argument from anarchy does not work, but they implicitly or explicitly concede that premise $\mathrm{C}$ is correct. Allen Buchanan, for example, rejects premise B by arguing that states are not morally allowed to prioritize their own inhabitants' survival because their survival is not always at stake in international politics. ${ }^{35}$ Implicitly he seems to be conceding that whenever survival is indeed at stake, states are morally allowed to prioritize survival over moral concern for foreigners. Jack Donnelly also rejects premise B by arguing that it is often safe for states to act morally in the international arena. However, he concedes that there may be 'good policy reasons in particular cases to pursue an amoral, or even immoral, policy. ${ }^{36}$ And he also claims that 'political leaders may be guilty of grievous political misconduct if, in the pursuit of some moral goal, they were to sacrifice [...] the lives of its citizens.' 37

Finally, other moralist critics correctly notice that premise $\mathrm{C}$ is problematic, but they fail to adequately explain why. Marshall Cohen, for example, not only rejects premise B (by arguing that not all foreign policy aims are inextricably tied to physical survival) but he also questions premise $\mathrm{C}$ by claiming that 'an exclusive concern for one's own [...] security at the expense of support for one's moral friends, or for those in distress, is open to other kinds of moral objection.' ${ }^{38}$ Cohen here opens the door to moral objections to premise C's alleged priority of compatriots over foreigners. Unfortunately, Cohen does not specify which kinds of moral objection premise $\mathrm{C}$ is open to, nor when exactly those objections apply.

In sum, current moralist critiques against the argument from anarchy are incomplete. First, although those critiques show that premises A and B do not hold in their stronger forms, I have argued that in weaker forms those premises are plausible. Anarchy and risks to security do exist in some circumstances and times, and trade-offs between security and poverty reduction are sometimes inevitable. Second, since current moralist critiques either accept premise C or they do not reject the premise adequately, moralists cannot resist the conclusion that in those particular circumstances and times when inhabitants' physical survival is at stake, national security may be rightly prioritized over all (other) moral considerations, especially over moral concern for the poor abroad.

34 Ibid. pp. 52, 55 .

35 Buchanan (2010), p. 118.

36 Donnelly (1993), p. 106.

37 Ibid. p. 105.

38 Marshall Cohen, 'Moral Skepticism and International Relations', Philosophy \& Public Affairs 13/4 (1984), 299-346, p. 316. 


\section{Completing the moralist critique}

The first problem with premise $\mathrm{C}$ is that it is incomplete. Why exactly does national security - understood as a concern for the physical survival of a state's inhabitants - have priority over all competing moral concerns? One plausible answer is that human beings have a fundamental right to life (understood as including at least a right to physical survival). The right to life may be regarded as a fundamental right in itself, 39 as necessary for enjoying other fundamental rights, ${ }^{40}$ or as implied by other fundamental rights, such as the right to autonomy..$^{41}$ Since fundamental moral rights outweigh non-fundamental moral considerations, grounding national security in the fundamental right to life implies that national security has priority over all non-fundamental moral considerations.

Appealing to the right to life, however, is not enough to make sense of premise C. After all, national security is not the only means by which a state may secure the right to life. Consider for instance domestic economic development. A low level of economic development in a state compromises its inhabitants' right to life. If a sufficiently high amount of domestic resources are channeled to national security, domestic economic development could be harmed to the point of causing starvation and death among the very same people that are being protected from foreign aggression. It is not at all clear that in such circumstances national security has priority over the concern for economic development, since both concerns are grounded in the right to life.

The same problem arises with moral duties towards other states' inhabitants, in particular the duty to reduce extreme global poverty. One of the reasons why states have a duty to reduce severe global poverty is that poverty causes premature death, and human beings have a right to life. It seems, thus, that national security and global poverty relief share the same rationale: securing the right to life. Why, then, should the former be prioritized over the latter? ${ }^{42}$ Absent a convincing answer, states would not have a permission to disregard global poverty reduction when national security is at stake (see the fourth section for some attempts at an answer, including the claim that all other things equal states are allowed to partially prioritize their own inhabitants). Instead,

39 See for example John Locke, Two Treatises of Government (Cambridge: Cambridge University Press, 1988), p. 42.

40 Henry Shue, Basic Rights: Subsistence, Affluence, and U.S. Foreign Policy (Princeton, N.J.: Princeton University Press, 1980), p. 19.

41 James Griffin, On Human Rights (Oxford; New York: Oxford University Press, 2008), p. 215.

42 Cécile Fabre also highlights that national self-defense and the fight against poverty have a common underlying rationale, since both are responses to threats to life and limb. However, her argument goes in a different direction from the argument I develop in this article. She claims that if threats to life by foreigners provide a just cause for waging war against them, then severe poverty culpably caused by foreigners also provides a just cause for waging war against them. Cécile Fabre, Ch.3, 'Subsistence Wars' in Cosmopolitan War (Oxford: Oxford University Press, 2012). 
states would have to assess which course of action in a given context would protect more lives. Are more lives saved by attending to national security, to global poverty, or partially to both?

To illustrate the point, take for example the most straightforward example of aim incompatibility mentioned above, the one in which resources need to be divided between the defense budget and the foreign aid budget. Perhaps in South Korea's particular case more lives could be saved by spending most available resources on defense instead of spending them on foreign poverty relief. But most other affluent states would probably secure more lives if resources that are currently being used for national defense were spent on development aid instead. So if realists want to claim that these other states should prioritize national defense over their moral duties, they need to provide a more complete answer. (In what follows I focus my challenge to realism on the moral duty to reduce poverty, leaving aside other moral duties such as the duty to secure the right to life of one's own compatriots through domestic economic development).

Realists could try to vindicate premise $\mathrm{C}$ by arguing that national defense is a form of self-defense. ${ }^{43}$ More specifically (since I am interpreting national defense in individualist terms) national defense is self-defense by individuals. Self-defense justifications are strong, in the sense that they are capable of justifying actions that are normally regarded as severely wrong. For instance, killing a human is normally severely wrong, but in the case of individual selfdefense, it is permissible (with some restrictions) to kill a lethal aggressor. ${ }^{44}$ Arguably it is even permissible to kill an innocent lethal aggressor (as in Robert Nozick's famous 'falling man' case.) 45 Now, the moral duty not to kill innocents is an important one. If self-defense justifications can go as far as allowing agents to disregard this important moral duty, then they plausibly also entitle agents to disregard less important moral duties, such as the duty not to lie, and maybe even the duty not to let others die (from starvation or other causes). After all, fighting global poverty involves not self-defense but other-defense: it is about saving someone else's life. ${ }^{46}$

The first problem with understanding premise $\mathrm{C}$ as a claim about national self-defense is that the self-defense justification has its limits. Not everything

43 David Rodin explains that the view that national defense is a form of self-defense has been a standard view since at least the early Middle Ages. David Rodin, War and Self-Defense (Oxford: Oxford University Press, 2002), p. 5.

44 Samuel Pufendorf, De Jure Naturae et Gentium Libri Octo, ed. C. H. Oldfather and W. A. Oldfather (New York: Oceana, 1964), bk. 2.5.

45 Robert Nozick, Anarchy, State, and Utopia (New York: Basic Books, 1974), p. 34.

46 In a sense, national defense is also mostly a matter of other-defense rather than self-defense: most inhabitants do not defend themselves, but they are defended instead by armed forces and public officials. However, it is plausible to claim that public officials and armed forces often act on behalf of the state's inhabitants, so national defense is, after all, self-defense. 


\section{GUNS OR FOOD: ON PRIORITIZING NATIONAL SECURITY OVER GLOBAL POVERTY RELIEF}

is morally permitted when defending oneself. As just war theory and personal self-defense theory bring out, self-defensive action is subject to the necessity and proportionality conditions. Only if these two conditions are met is it permissible to use deadly force against (culpable and innocent) aggressors and bystanders. Arguably, those two conditions also apply - in a qualified form - to cases in which self-defense requires letting innocents die (either from poverty or from other causes).

Consider first the necessity condition, or last resort condition: killing in selfdefense is permissible only if there is no other less harmful way to achieve the defensive aim. ${ }^{47}$ This condition is met when there is a conflict between national self-defense and global poverty reduction. After all, the very fact that there is a conflict between two considerations (i.e. that there is no course of action in which both considerations could be simultaneously met) implies that there is no other way to achieve one aim without sacrificing the other. And if there is no other way, then there is no less harmful way. Of course, one may doubt whether it is ever the case that there is really no other way to improve national defense besides cutting back on the fight against poverty, i.e., one may doubt premise B. But we saw above that at least in its weak version this premise is plausible.

Consider now the proportionality condition. This condition is met when the morally weighted benefits achieved by self-defensive means outweigh the morally weighted costs that those means will bring about. ${ }^{48}$ As mentioned above, killing a lethal aggressor is usually regarded as proportionate, even if the aggressor is innocent. If it is proportionate to kill an innocent person in defending yourself, it is surely proportionate to let an innocent person die in defending yourself (as in the case of letting a foreigner die of poverty). Therefore, the proportionality condition seems to be met when national defense and global poverty reduction clash.

But the proportionality condition is sensitive to numbers. For instance, it is impermissible to wage self-defensive war (or to perform a particular act during a war) if the number of innocents that would likely be killed is sufficiently higher than the number of people that would be saved from an unjust military aggression. Along the same lines it could be argued that if the number of people that would be necessarily left to die by engaging in self-defense is sufficiently higher than the number of people that would be saved from a foreign aggression, it is impermissible to engage in self-defense and leave the former to die. Now, this sort of disproportion sometimes occurs when national defense

\footnotetext{
47 Seth Lazar, 'War', The Stanford Encyclopedia of Philosophy, 2016, sec. 2.5, <http://plato.stanford.edu/archives/ sum2016/entries/war/> (Accessed: 30 August 2017). 48 Ibid.
} 
and global poverty reduction clash. If, for instance, thousands could be saved from starvation with the money spent on building a single piece of armament that only marginally increases the chances of successfully defending just a few compatriots, then the proportionality condition is probably not met. Former U.S. president Dwight Eisenhower eloquently described this disproportion as follows:

The cost of one modern heavy bomber is this: a modern brick school in more than 30 cities. It is two electric power plants, each serving a town of 60,000 population. It is two fine, fully equipped hospitals. It is some 50 miles of concrete highway. We pay for a single fighter plane with a half million bushels of wheat. We pay for a single destroyer with new homes that could have housed more than 8,00o people. 49

The second problem with understanding premise $\mathrm{C}$ as a claim about national self-defense is that most efforts to increase national security do not strictly qualify as self-defensive action. Notice first that there are two different ways in which an agent may pursue the aim of national defense: (a) working now to increase the probability of successful self-defense against (or deterrence of) a potential, temporally distant attack; or (b) pre-empting an imminent attack or stopping an ongoing attack. (A threat of violent aggression is imminent when it is specific and temporally proximate. $)^{50}$

Strictly speaking, 'self-defense' only refers to cases in which an aggression is ongoing or imminent. It may seem arbitrary to limit the use of the term 'self-defense' only to those cases. However, when an aggression is ongoing or imminent, the defender acquires a set of extensive permissions that she does not acquire when the threat is not imminent or ongoing. For example, I am allowed to kill someone who is pointing a gun at me, but not someone who is planning to kill me next week, even if I am sure she is seriously planning it. At most, I may destroy the means she is planning to use (if I can do it without putting her at risk). Given their different moral implications, it is important to keep both types of cases apart. Thus it will be helpful to use a different term for each: 'self-defense' for imminent or ongoing threats, 'self-protection' for temporally more distant threats.

Most of the time affluent countries are not facing any imminent or ongoing foreign aggression, at least since the end of World War II. A substantial amount of resources they allocate to national security is directed at deterring, and

49 Dwight David Eisenhower, 'The Chance for Peace', in White House Ghosts: Presidents and Their Speechwriters, ed. Robert Schlesinger (New York: Simon \& Schuster, 2008), pp. 74-75.

50 Noam Lubell, 'The Problem of Imminence in an Uncertain World', in The Oxford Handbook of the Use of Force in International Law, ed. M. Weller, Alexia Solomou, and Jake William Rylatt (Oxford: Oxford University Press, 2015), 697-719. 


\section{GUNS OR FOOD: ON PRIORITIZING NATIONAL SECURITY OVER GLOBAL POVERTY RELIEF}

preparing themselves against, unspecified and temporally distant attacks. So we need to re-describe the normative conflict that affluent states most often face between national security and global poverty relief. What states really have to choose between is: taking a certain measure that reduces the risk of civilian death by a non-specific, temporally distant foreign aggression, and taking an alternative measure that reduces the risk of death of destitute foreigners by a specific, temporally proximate lethal threat: hunger, lack of shelter, or lack of basic health care. This is not a conflict between self-defense and poverty relief, but a conflict between self-protection and poverty relief.

May national self-protection be prioritized over poverty relief? Individual self-protection is subject to the same proportionality constraint as individual self-defense, but the constraint is even more demanding in the case of selfprotection. Letting people die as a means of self-protection can only be justified if the number of individuals that are being protected is substantially larger than the number of individuals that are being let to die. So in cases where a state must choose between protecting a number of people from future military aggression and saving an equal or even moderately larger number of people from death by poverty, the state must choose the latter.

\section{Objections}

Realists could try to rescue premise $\mathrm{C}$ by resorting to the idea of role duties. Persons occupying social roles are expected to comply with certain duties, and this fact seems to have some moral weight. For instance, the role of being a public intellectual seems to generate a moral duty to think diligently and seriously about current political issues. Similarly, state leaders are expected to further national security. ${ }^{51}$ In this vein, a realist could argue that if a state leader ever sacrificed national security in order to reduce global poverty, she would be violating her role duties and therefore committing a moral wrong.

Of course, not all role duties are also moral duties. The mere fact that an agent plays a role that is customarily associated with certain duties does not mean that these are moral duties, or that she has moral permission to comply with them. The leader of a suicidal cult may have a role duty to administer poison to the other cult members, but that is not enough to show that she has an actual moral duty or permission to administer it. In order to be actual moral duties, role duties have to be morally justifiable. ${ }^{52}$ Now, the realist is right in claiming that the role of a state leader is not like that of a suicidal cult leader. In broad terms, the duties that are associated with being a state leader seem

51 Morgenthau (2016), p. 42; Michael Walzer, Arguing about War (New Haven, CT: Yale University Press, 2004), p. 42. 52 Anthony Coady, 'The Problem of Dirty Hands', The Stanford Encyclopedia of Philosophy, 2014, sec. 4, <http://plato. stanford.edu/archives/spr2014/entries/dirty-hands/> (Accessed: 30 August 2017). 
to be morally justifiable: securing human rights for its inhabitants, promoting equality, increasing national security, etc. all seem to be morally permissible and even morally required activities.

Notice, however, that even morally justifiable role duties are not morally supreme. They are sometimes outweighed by general moral duties. ${ }^{53}$ Consider the case of a priest who hears in confession that someone is planning to murder someone else. It seems that the general moral duty to protect the third person from being killed outweighs the priest's (morally justifiable) role duty to keep confessions confidential. So in some extreme cases, general morality can outweigh role morality. Now, the appeal to role duties by those defending the argument from anarchy seems to operate in the opposite way. ${ }^{54}$ The idea seems to be that in cases which are not extreme (when national security is not at stake), political leaders must conform to general moral duties, while in cases which are extreme general duties are outweighed by role duties.

Thus if role duties are to be part of a realist argument for prioritizing national security, a different sort of argument needs to be made. Realists need to show that political roles are not like most roles. They need to show that general moral duties, which usually outweigh role obligations in extreme cases, are not strong enough as to outweigh political role obligations.

But what makes political roles so special? The usual answer here is that international political action is special because it takes place in an anarchic realm. In anarchic realms life is at stake, so international political action is subject to less strict moral constraints than action in less risky realms. The problem with this answer is that at this point the recourse to the idea of role duties becomes superfluous. That idea was supposed to supplement the argument from anarchy, not just repeat it.

Another option open to realists is to try to vindicate premise $\mathrm{C}$ by resorting to the idea of reasonable partiality for co-nationals or compatriots. In the global justice debate nationalists and statists argue that the fact of sharing a nation or a state (respectively) can ground special duties regarding socioeconomic distribution, defense, etc. which allow or even require prioritizing a state's inhabitants over non-inhabitants. This view is criticized by cosmopolitans, who argue that special relationships such as nationality or statehood cannot ground a permission (or a duty) to be partial, or that those relationships only ground a permission to be partial once certain basic general duties towards all human

53 Brian Barry, Liberty and Justice: Essays in Political Theory 2 (Oxford: Clarendon, 1991), pp. 165-6; Caney (2005), p. 140.

54 Coady (2014), sec. 4 


\section{GUNS OR FOOD: ON PRIORITIZING NATIONAL SECURITY OVER GLOBAL POVERTY RELIEF}

beings have been reasonably fulfilled. ${ }^{5}$ In the remaining of this section I argue that regarding the right to life nationalism and statism can justify a kind of priority for a state's inhabitants that is, at most, remarkably weak.

There are two kinds of view about justified partiality towards co-inhabitants: instrumental and non-instrumental (or principled) views. Instrumentalist views grant that as a matter of principle there is no difference between a state's duties towards inhabitants and towards non-inhabitants, so the same duties to secure physical survival are owed equally to all. However, instrumentalist views argue that an effective way to fulfill those duties is to distribute them among states. ${ }^{56}$ If each state focuses on securing survival to its own inhabitants before taking care of non-inhabitants, the overall amount of individuals who will see their physical survival being secured will be higher than if each state tries to secure physical survival to all human beings at once.

The main problem with instrumental views is that they depend on it being empirically true that prioritizing inhabitants over non-inhabitants is the best available way to fulfill general duties. As even instrumentalist authors concede, in the present world system the empirical conditions for an effective distribution of general duties are not met. ${ }^{57}$ On one hand, some states are incapable or unwilling to adequately secure their inhabitants right to life, so if other more able or willing states do not help - even at some cost to their own inhabitants' right to life - , the overall satisfaction of that right would probably be lower. On the other hand, developments in communication and transport make it easier than in the past for a state to secure the right to life of people in other states. Therefore, the claim that states are sufficiently more efficient in securing that right in their own territories than in other territories - so as to justify a strict division of moral labor between states - is doubtful.

Non-instrumental views, on the other hand, claim that there are principled reasons for at least sometimes prioritizing state inhabitants over noninhabitants. ${ }^{58}$ At first sight, these views seem to be denying that all human beings have equal moral worth. Indeed, such views seem to imply that not all humans should be treated equally, with some deserving preferential treatment due to arbitrary facts such as place of birth. Non-instrumentalist views try to meet this egalitarian challenge in two ways. One way is to claim that allowing for special duties towards compatriots does not imply denying the principle of

\footnotetext{
55 Tan (2004), p. 158.

56 Robert E. Goodin, ‘What Is So Special about Our Fellow Countrymen?', Ethics 98/4 (1988), 663-686, p. 678; Gillian Brock, 'Global Justice, Cosmopolitan Duties and Duties to Compatriots: The Case of Healthcare', Public Health Ethics 8/2 (2015), 110-120, p. 113.

57 Goodin (1988), p. 686.

58 Miller (2007); Nagel (2005).
} 
equal moral worth, because those duties are simply the result of applying the principle of equal moral worth to particular circumstances. ${ }^{59}$ The other attempt to meet the egalitarian challenge is to grant that there is a tension between duties that arise from the principle of equal worth and duties that arise from the non-instrumental value of special relationships, but since we have good reasons to acknowledge both kinds of duties we must try to find a reasonable accommodation between them. ${ }^{60}$ Instead of assessing whether these answers are plausible in terms of their grounds, I will assess them in terms of their implications. Consider a case in which due to limited resources a state is forced to choose whether to secure physical survival to one of its inhabitants - whose life is threatened by foreign military aggression - or to a non-inhabitant - whose life is threatened by severe poverty. Both non-instrumentalist views claim that, all other things equal, the state must prioritize its own inhabitant because on top of the state's general duty to protect the lives of both individuals, the state has an adequately grounded special duty to its own inhabitant. In terms of the principle of equal moral worth, both individuals equally deserve protection. But special duties break the tie.

Now imagine that instead of having to choose between two individuals (one inhabitant and one non-inhabitant), a state is forced to choose between securing physical survival to a single inhabitant and securing physical survival to two noninhabitants. Are special duties to the inhabitant strong enough as to outweigh the general duty to secure physical survival to one additional non-inhabitant? It seems to me that we cannot allow special duties that much strength, at least as long as we are committed to the principle of equal moral worth of all human beings, and to the idea that the right to life is truly fundamental (while nationhood - and statehood - based rights are not). Therefore, non-instrumentalist forms of nationalism and statism are only capable of justifying a weak kind of priority: priority in cases of complete tie-break. As soon as the choice involves a slight difference in terms of the number of individuals in danger, all traces of priority vanish.

\section{Concluding remarks}

The argument from anarchy makes a strong case for the claim that affluent states may disregard their duties to reduce extreme world poverty. The argument points out that fighting poverty abroad sometimes compromises national security, and in an anarchic international arena this means that individual lives are put at risk. The present article has argued that national security reasons have their

59 Blake (2001), pp. 260-261.

60 Samuel Scheffler, Boundaries and Allegiances: Problems of Justice and Responsibility in Liberal Thought (Oxford: Oxford University Press, 2002), p. 7; 76. 
limits. After all, fighting extreme global poverty is about saving lives as well. Actions promoting national security must meet proportionality constraints. It is impermissible to increase national security for a certain number of people at the cost of omitting an action that could save a larger number of people from severe poverty abroad. This proportionality constraint is especially stringent when aggression against affluent states is neither ongoing nor imminent, but relatively distant, as is sometimes the case for affluent states. Two attempts to salvage the argument from anarchy were analyzed and found lacking. Appeals to political leaders' role duties and to the alleged priority of compatriots or conationals are not enough to show that national security has priority over global poverty relief. ${ }^{61}$

Francisco García-Gibson

Research Assistant

Universidad de Buenos Aires

email:fgarciagibson@derecho.uba.ar

the global justicenetwork

61 I would like to thank Charles Beitz, Cristián Rettig, Jürgen Sirsch, and participants at the Symposium on Human Rights, Exploitation and Cosmopolitan Justice (Buenos Aires, 2016) for their invaluable comments. 